\title{
Effects of 17 $\alpha$-methyltestosterone on the reproduction of the freshwater snail Biomphalaria glabrata
}

\author{
C.L.G. Rivero-Wendt ${ }^{1}$, A.C. Borges ${ }^{1}$, E.C. Oliveira-Filho ${ }^{2}$, \\ A.L. Miranda-Vilela ${ }^{1,3}$, M.F.N. Ferreira ${ }^{1}$ and C.K. Grisolia ${ }^{1}$ \\ ${ }^{1}$ Departamento de Genética e Morfologia, Instituto de Ciências Biológicas, \\ Universidade de Brasília, Brasília, DF, Brasil \\ ${ }^{2}$ Laboratório de Ecotoxicologia, Embrapa Cerrados, Planaltina, DF, Brasil \\ ${ }^{3}$ Faculdades Integradas da União Educacional do Planalto Central, \\ Curso de Medicina, Gama, DF, Brasil \\ Corresponding author: C.K. Grisolia \\ E-mail: grisolia@unb.br
}

Genet. Mol. Res. 13 (1): 605-615 (2014)

Received December 21, 2012

Accepted April 11, 2013

Published January 28, 2014

DOI http://dx.doi.org/10.4238/2014.January.28.6

\begin{abstract}
MT) is a synthetic hormone used in fish hatcheries to induce male monosex. Snails hold promise as possible test models to assess chemicals acting on the endocrine system. Biomphalaria glabrata is an aquatic gastropod mollusk (Pulmonata, Planorbidae) that can be easily maintained in aquaria, predisposing the species for use in ecotoxicological testing. This study evaluated the reproductive effects of MT on B. glabrata by examining histological changes and its reproductive performance. Ten snails per group were exposed for 4 weeks to different concentrations of MT $(0.01,0.1$, and 1.0 $\mathrm{mg} / \mathrm{L})$. The total number of laid eggs, egg mass per group, size of type $\mathrm{V}$ oocytes, and production of spermatozoids were determined. Reproduction of B. glabrata was affected by MT. At the lowest concentration (0.01 $\mathrm{mg} / \mathrm{L})$, MT caused a statistically significant increase in the number of egg mass per snail compared with controls unexposed to MT. Histopathology analyses showed an increase in the sperm production at the higher MT
\end{abstract}


concentrations of 0.1 and $1.0 \mathrm{mg} / \mathrm{L}$. Chromatographic analyses of water samples showed that MT concentrations rapidly declined within a 96-h period. These results highlight the importance of giving more support to regulatory authorities, since MT is not registered for use on fish hatcheries in many countries around the world. Wastewater from fish farms discharged into aquatic ecosystems should be monitored for MT residues, since its presence could compromise the reproduction of other native snail species.

Key words: $17-\alpha$-methyltestosterone; Reproductive performance; Endocrine disruptor; Biomphalaria glabrata; Histopathology

\section{INTRODUCTION}

Xenobiotics in the environment have been shown to induce adverse effects in animals and humans by interfering with endocrine functions. These effects include increased frequencies of sex hormone-dependent cancers (breast, testis, prostate, etc.), genital abnormalities, premature puberty in females, and increased occurrence of endometriosis in humans (Gist, 1998; Swan et al., 2000).

The androgenic effects of environmental endocrine-disruptor chemicals on aquatic organisms have received increased attention, since these organisms are the target of chemicals that induce sexual reversion (Papoulias et al., 2000). One such chemical, 17- $\alpha$ methyltestosterone (MT), is a synthetic hormone used in fish hatcheries to induce anabolic and androgenic effects (Vick and Hayton, 2001), including sexual reversion in cultivated fish species. MT is widely used as a reference chemical to induce male monosex and is considered an endocrine disrupter in fish (Smith, 1974; Pandian and Sheela, 1995; Ankley et al., 2001; Zerulla et al., 2002; Arslan and Phelps, 2004; Pawlowski et al., 2004; Hornung et al., 2004; Kang et al., 2008; Grisolia et al., 2009). Accordingly, there is a concern about, and resistance to the use of these hormones in food production, and more efforts should be made to better understand how androgenic chemicals used in aquaculture adversely affect wildlife.

In aquatic environments, invertebrates represent more than $90 \%$ of the species in these environments (Jha, 1998). Gastropod mollusks appear to be a reliable invertebrate model for evaluations of xenobiotics, enabling analysis of successive stages of their lifecycle for assessing the ecological impact of chemicals (Gourmelon and Ahtiainen, 2007). Mollusks are effective sentinels because they are ubiquitous, have highly conserved regulatory pathways, and are sensitive to anthropogenic inputs (Gupta and Singh, 2011).

Typical responses of mollusks to androgens include the development of imposex (occurrence of male sex characteristics superimposed on female gastropods) and a reduction of fertility or embryo production in the freshwater mudsnail (Potamopyrgus antipodarum), the freshwater ramshorn snail (Marisa cornuarietis), and the marine netted whelk (Nassarius reticulates) (Duft et al., 2007). Disturbances in their metabolism, development, and reproduction are of concern for the preservation of biodiversity in ecosystems. In fact, the reproduction of aquatic organisms is one of the endpoints currently employed to evaluate the effect of toxicants (Gomot, 1998; Cheung and Lam, 1998; Cervera et al., 2004; Coeurdassier et al., $2003,2004,2005)$. The use of mollusks as test organisms is becoming widespread, since they are able to accumulate contaminants and facilitate the detection of minute amounts of trace 
contaminants (Elder and Collins, 1991). Biomphalaria glabrata is sensitive to bisphenol A and phthalates, which promote endocrine disruption and increase oviposition (Iqbal and Sinha, 2011). However, few studies have been performed assessing the possible effects of MT on invertebrates like B. glabrata, such as effects on reproduction. Freshwater mollusks of the genus Biomphalaria are distributed all over the word and considered to be good indicators for biomonitoring studies (Abd-Allah et al., 1999; Nakano et al., 2003; Ansaldo et al., 2006).

The present study was designed to test the hypothesis that MT may affect crucial stages of the reproductive cycle of $B$. glabrata, i.e., number of eggs, egg mass, maturation of oocytes, and spermatozoid production.

\section{MATERIAL AND METHODS}

\section{Test organism}

B. glabrata (Mollusca; Gastropoda) is a tropical freshwater pulmonate snail found in Brazilian water bodies. It is a simultaneous hermaphrodite and can breed by self- and crossfertilization. At $25^{\circ} \mathrm{C}$, egg laying generally starts when snails are approximately 2 months old, and young snails hatch between the 6th and 9th day after oviposition (Paraense, 1972). Biomphalaria snails are easily bred and kept under laboratory conditions and have been shown to be sensitive to reproductive impairment caused by endocrine disruptors (Oliveira-Filho et al., $2009 \mathrm{a}, \mathrm{b})$. All snails used in this study originated from a breeding stock of B. glabrata maintained at the Laboratory of Ecotoxicology of Embrapa Cerrados.

\section{Test medium, test substances, and effective concentrations}

All snails were kept in synthetic soft water $(\mathrm{pH} 7.2 \pm 0.1$, hardness $40-48 \mathrm{mg} / \mathrm{L}$ as $\mathrm{CaCO}_{3}$ ) prepared as recommended by guidelines of the Brazilian Association for Technical Standardization (ABNT, 2004). The hormone MT (90\% purity) was purchased from Bioativa pharmacy (Paraná, Brazil). The nominal concentrations were prepared from a stock solution $\left(23 \mathrm{mg} / \mathrm{L}\right.$ ) by dissolving MT in absolute ethanol (density $0.790-0.793 \mathrm{~g} / \mathrm{cm}^{3}$ at $20^{\circ} \mathrm{C} ; 99.9 \%$ purity from Merck). MT was added in absolute ethanol $(0.005 \mathrm{~mL})$ to reach a concentration of $0.001 \%$ ethanol in water.

\section{Chemical analysis of MT in water}

Fifty-milliliter samples of water containing MT at concentrations of 0.01 and $1.0 \mathrm{mg} / \mathrm{L}$ were collected at the beginning and end of the first week of each experiment to evaluate MT degradation under laboratory conditions; samples were stored at $4^{\circ} \mathrm{C}$. The analytical method used for determining MT was an adaptation of the method by Falone (2007) for analysis of MT in water samples and sediments from fish farms. Solid-phase extraction was carried out by using cartridges with silica-gel stationary phase chemically bonded to the nonpolar organic group C18. The cartridges of polypropylene syringes (AccuBondII - Agilent Technologies) contained $1000 \mathrm{mg}$ of stationary phase and had a volume of $6 \mathrm{~mL}$. Conditions for solid-phase extraction were the following: C18 - cartridge methanol/water $(1: 1, \mathrm{v} / \mathrm{v})$, ethanol as solvent for eluting the analyte, a volume of $5 \mathrm{~mL}$ solvent for extraction, and a final volume of $3 \mathrm{~mL}$ con- 
taining the analyte. After performing extraction of the water samples, high-performance liquid chromatography was used for quantifying MT (Perkin Elmer series 200). Chromatographic conditions were as follows: an injected volume of $20 \mu \mathrm{L}, \mathrm{C} 18$ - octadecylsilane as stationary phase, flow rate of $0.4 \mathrm{~mL} / \mathrm{min}$, and UV-Vis detection at a detection wavelength of $236 \mathrm{~nm}$. The mobile phase was methanol/water $(80: 20, \mathrm{v} / \mathrm{v})$ run as an isocratic gradient. The retention time of MT was $11.6 \mathrm{~min}$ at room temperature. Chromatographic standard was previously determined by using a reference MT (Sigma) to show the retention time between 12 and $13 \mathrm{~min}$.

\section{Experimental design}

This study evaluated the effects of MT on the fecundity of mature $B$. glabrata. Threemonth-old snails were individually incubated for 4 weeks in glass vessels of $300 \mathrm{~mL}$ under controlled environment conditions $\left(25^{\circ} \pm 1{ }^{\circ} \mathrm{C}\right.$ and light/dark cycle of $\left.16 / 8 \mathrm{~h}\right)$. The test solutions were renewed twice weekly and snails were fed with fresh lettuce leaves grown without pesticides (the size of each piece was approximately $1 \mathrm{~cm}^{2}$ ) and a small flake of commercial fish chow. Snails ( $\mathrm{N}=10$ per group) were exposed to water containing MT according to the following treatments: 1) synthetic soft water (negative control), 2) MT at $0.01 \mathrm{mg} / \mathrm{L}, 3$ ) MT at $0.1 \mathrm{mg} / \mathrm{L}$, and 4) MT at $1.0 \mathrm{mg} / \mathrm{L}$. To recover egg masses laid by snails, glasses were internally covered with cellophane sheets as suggested by Olivier and Haskins (1960) and adapted by Oliveira-Filho et al. (2009a,b). Cellophane sheets were changed twice weekly and numbers of eggs and egg masses per snail were recorded. Egg and egg mass production of snails were evaluated for 4 consecutive weeks, a time considered by Oliveira-Filho et al. $(2009 a, b)$ as sufficient for the observation of reproductive effects on snails.

After incubation with and without MT, 50 snails were anesthetized with lidocaine gel, the shell removed, and soft bodies fixed with Davidson solution for $24 \mathrm{~h}$; this was followed by transfer to $70 \%$ ethanol and embedding in paraffin using an automatic tissue processor $\left(\mathrm{OMA}^{\circledR}\right.$ DM-40, São Paulo, Brazil). Specimens were cut into 5- $\mu \mathrm{m}$ sections using a Leica RM2235 manual microtome (Leica Microsystems, Nussloch, Germany) and stained with hematoxylineosin for histological analyses by light microscopy. Oocytes were classified into 5 stages according to the maturation scale by Wallace and Selman (1981). Morphometric analyses were performed with the Image-pro Plus 5.1 software. Thirty oocytes at stage V (mature oocytes) of each treatment were analyzed for the completion of vitellogenesis and the diameter of the oocytes (Homklin et al., 2011). Quantification of sperm was performed with the same program. Photomicrography at a magnification of $400 \mathrm{X}$ was performed for sections of negative control and MT-exposed snails. Ten seminiferous tubules from the proximal portion of gonads were selected to calculate the area occupied by sperm in gonads to evaluate whether addition of MT stimulated or inhibited the growth of the reproductive system.

\section{Statistical analysis}

Differences in the number of produced eggs and egg masses between the tested groups and the control group were evaluated by one-way ANOVA followed by the Dunnett multiple comparison test (Dunnett, 1955). The Dunnett procedure software (Version 1.5) was available from the United States Environmental Protection Agency. The GraphPad Prim 5.0 software was used to analyze oocyte and spermatozoid data, and possible statistically significant dif- 
ferences between the groups were analyzed by ANOVA for data having a normal distribution or the Kruskal-Wallis test for data lacking a normal distribution, followed by Bonferroni or Mann-Whitney-U post hoc tests, respectively.

\section{RESULTS}

\section{Reproductive performance}

The effects of a 4-week exposure to MT on the fecundity of B. glabrata are shown in Figure 1A and B. Exposure to MT at all concentrations tested for 4 weeks did not cause any significant differences in the number of eggs produced per snail compared with the control group or with the ethanol group. On the other hand, at the lowest concentration of 0.01 $\mathrm{mg} / \mathrm{L}, \mathrm{MT}$ caused a statistically significant $(\mathrm{P}<0.05)$ increase in the number of egg masses per snail $(26.9 \pm 1.5$; mean \pm SE) compared with the control $(20.1 \pm 2.6)$ and ethanol $(17.0 \pm$ 1.6) groups. Ethanol used as solvent did not cause toxicity in B. glabrata in the treatments: no deaths occurred in any of the groups.
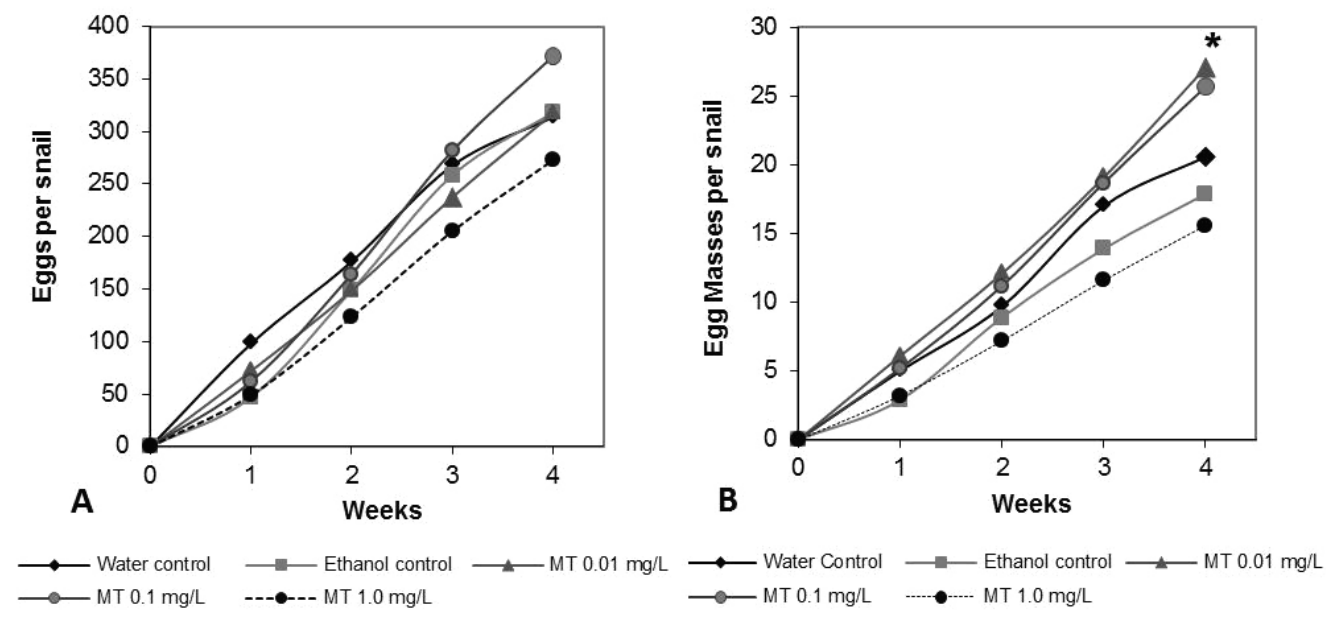

Figure 1. Cumulative means of eggs (A) and egg masses (B) of Biomphalaria glabrata exposed to $17 \alpha$-methyltestosterone (MT) and to ethanol/water for 4 weeks. $* \mathrm{P}<0.05$ indicates statistically significant differences compared to water control $(0 \mathrm{mg} / \mathrm{L})$ at the fourth week (ANOVA and Dunnett multiple comparison test).

\section{Histological and morphometric analysis of mature oocytes and sperm}

Histopathological changes were observed at $0.01 \mathrm{mg} / \mathrm{L} \mathrm{MT}$, indicated by early degeneration of the basal membrane surrounding the acinus, and by regression and detachment of germ cells (Figure 2). At the exposure level of $0.1 \mathrm{mg} / \mathrm{L}$, these alterations were persistent. In general, the gonad acini degenerated by forming a lumen, which could be observed as damaged connective tissue and by a compression causing the process of metaplasia that fused the 
basal membrane with the acinus. The morphology of oocytes was changed in the same process that causes atresia. At $1.0 \mathrm{mg} / \mathrm{L} \mathrm{MT}$, disruption of the basal membrane surrounding the acini was observed. The MT stimulated a large production of sperm; however, the oocyte production was maintained at normal level.
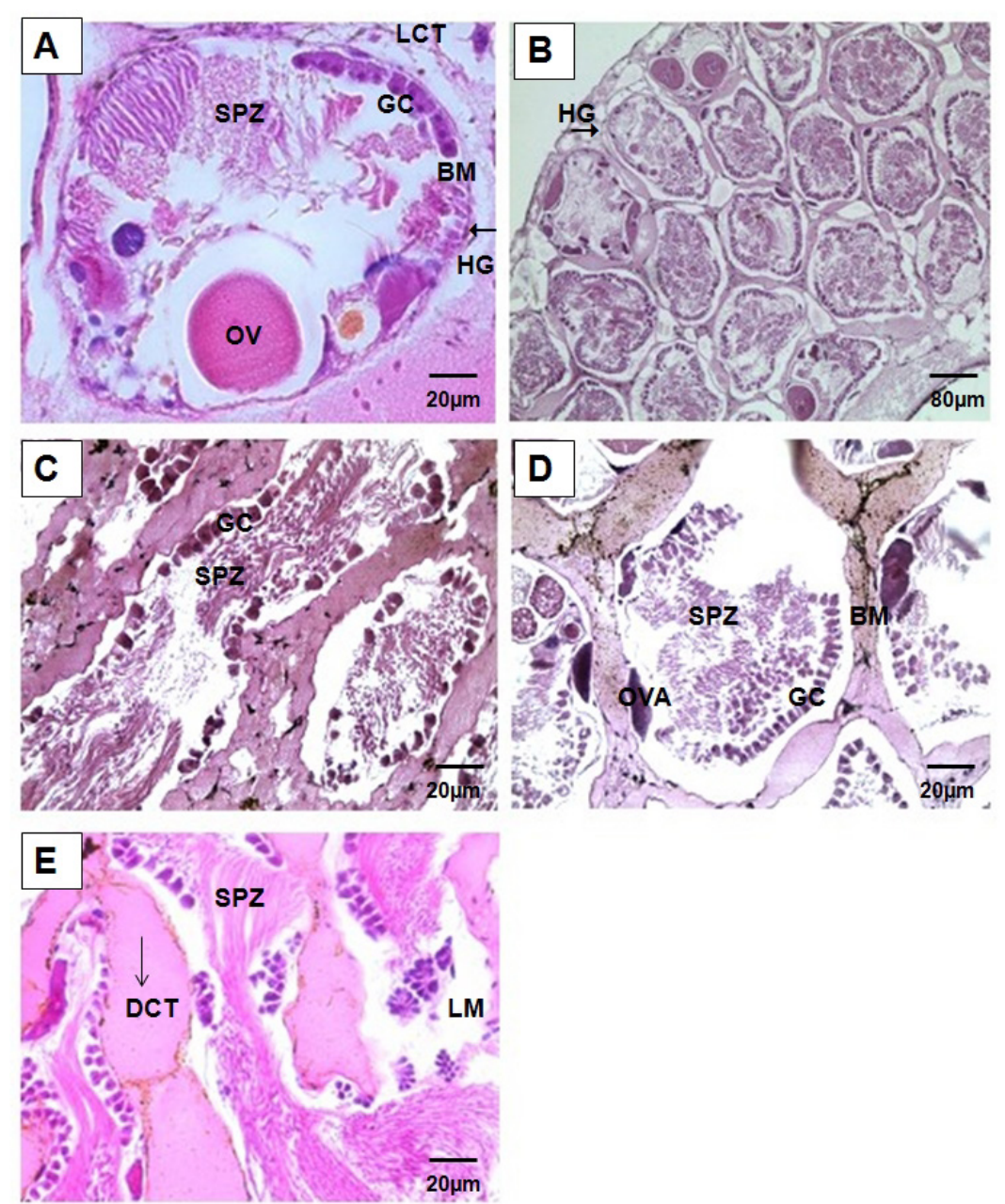

Figure 2. Gonad of Biomphalaria glabrata cross-sections of two control groups and three groups exposed to $17 \alpha$-methyltestosterone (MT) for 4 weeks. A. Control without ethanol - the presence of loose connective tissue inside the gonad and several acini delimited by a basement membrane associated with squamous epithelium presenting paired germ cells within the acinus; in the innermost part there are eggs and sperm; B. Control with ethanol - there are no morphological changes; C. $0.01 \mathrm{mg} / \mathrm{L}$ - degeneration of the basal membrane and the regression of germ cells; D. $0.1 \mathrm{mg} / \mathrm{L}$ - detachment of germ cells and formation of a lumen; E. $1.0 \mathrm{mg} / \mathrm{L}$ - breakdown of the basement membrane releasing the contents of the inner lobes followed by compaction of loose connective tissue in dense connective tissue, an increase in sperm production and continuing production of oocytes, increasing stem cells and formation of the lumen. Germ cells (GC), spermatozoids (SPZ), hermaphrodite gonad (HG), lumen (LM), basal membrane (BM), oocytes (OV) in oocyte atresia (OVA), loose connective tissue (LCT), dense connective tissue (DCT). 
Table 1 shows that the sizes of the mean areas of the mature oocytes were not statistically different from those in the control groups. In the sperm areas, the morphometric analyses showed a significant increase in sperm production at concentrations of 0.1 and $1.0 \mathrm{mg} / \mathrm{L} \mathrm{MT}$, compared with the water-control group. On the other hand, no such difference was observed between the MT-treated groups and the solvent-control group. Chromatographic analyses of water samples collected from glass vessels at the beginning and end of the first week indicated that at the lowest concentration level of $0.01 \mathrm{mg} / \mathrm{L}$, MT degradation was $99.6 \%$ (Figure 3), whereas at $1.0 \mathrm{mg} / \mathrm{L}, 81.7 \%$ of the hormone was no longer detectable in water (Figure 4).

Table 1. Means and standard deviation (SD) of mature oocytes and areas occupied by sperm in gonads of Biomphalaria glabrata, with or without exposure to the hormone $17 \alpha$-methyltestosterone (MT).

\begin{tabular}{lcr}
\hline & Spermatozoids $(\mu \mathrm{m})$ & Oocytes $(\mu \mathrm{m})$ \\
\hline Solvent control & $14201.41(15076.58)$ & $3627.21(1863.07)$ \\
Water control & $7327.22(9448.02)$ & $3234.16(2176.45)$ \\
$0.01 \mathrm{mg} / \mathrm{L}$ MT & $2618.03(1551.08)$ & $7649.86(8371.04)$ \\
$0.1 \mathrm{mg} / \mathrm{L}$ MT & $12919.73(8745.82)^{*}$ & $3006.34(2042.61)$ \\
$1.0 \mathrm{mg} / \mathrm{L}$ MT & $12671.74(9742.38)^{*}$ & $3204.10(1824.85)$ \\
\hline
\end{tabular}

$* \mathrm{P}<0.05$ represent a significantly difference between water control and MT exposure.

A
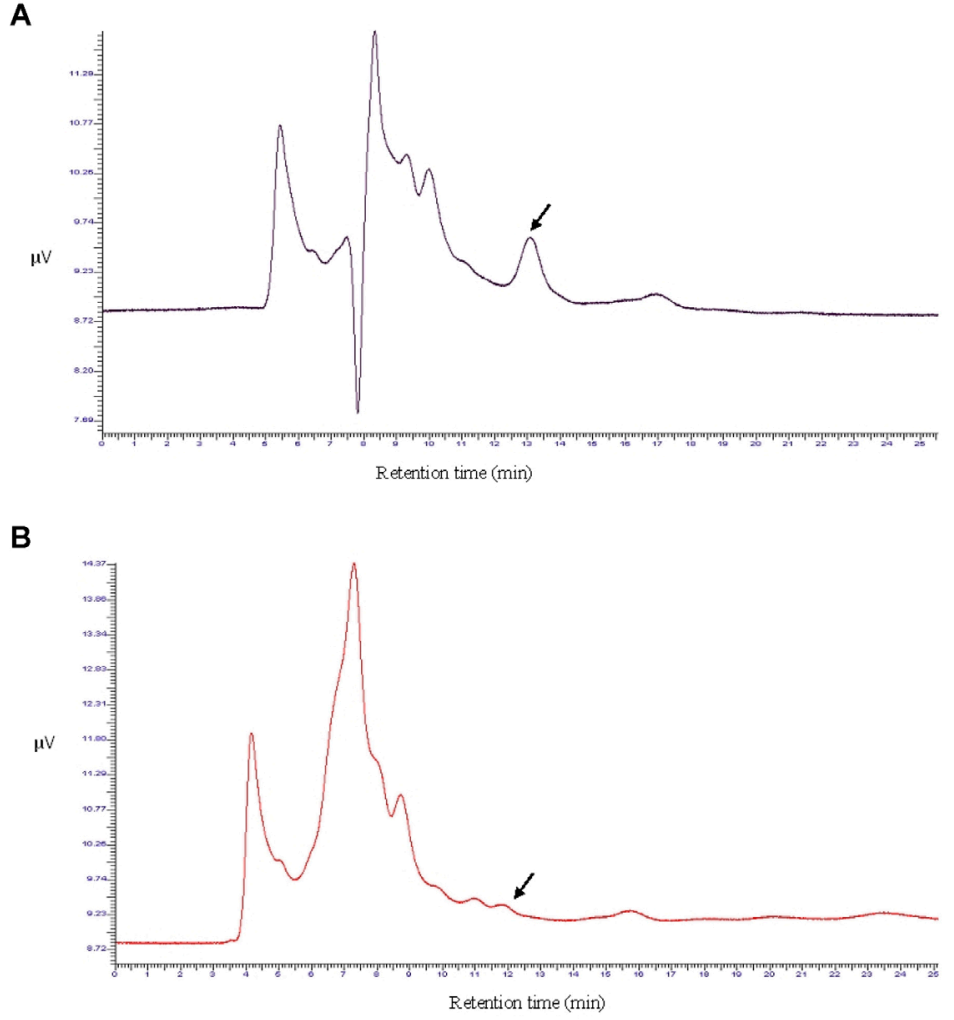

Figure 3. Chromatogram from glass vessel samples containing $0.01 \mathrm{mg} / \mathrm{L} 17 \alpha$-methyltestosterone (MT), taken at the beginning of exposure (A) and after a 96-h exposure (B). There was a consumption of $81.69 \%$ of the hormone in the period of $96 \mathrm{~h}$. Arrow shows the peak of MT at retention time between 12 and 13 min. 
A
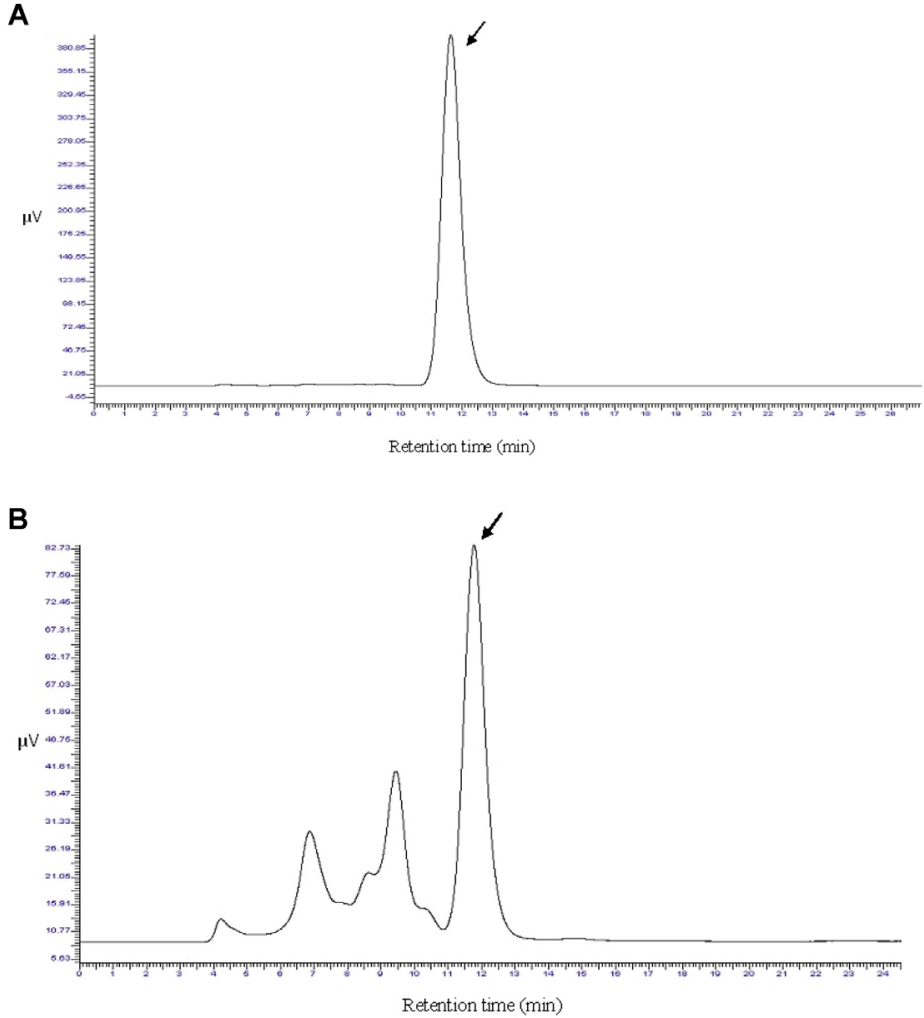

Figure 4. Chromatogram from glass vessel water samples containing $1.0 \mathrm{mg} / \mathrm{L} 17 \alpha$-methyltestosterone (MT), taken at the beginning of exposure (A) and after a 96 -h exposure (B). There was a consumption of $81.69 \%$ of the hormone in the period of $96 \mathrm{~h}$. Arrow shows the peak of MT at retention time between 12 and $13 \mathrm{~min}$.

\section{DISCUSSION}

In a previous study, sexually mature Limnaea stagnalis snails were exposed to MT for 8 weeks. MT did not affect the fecundity measured as number of egg masses produced, but at $100 \mathrm{ng} / \mathrm{L}, \mathrm{MT}$ exposure triggered degenerative processes of the albumen and prostate glands (Czech et al., 2001). Females of the freshwater ramshorn snail Marisa cornuarietis exposed to $300 \mathrm{ng} / \mathrm{L}$ MT had a significantly higher incidence of imposex than controls (Janer et al., 2006). Our results showed that MT did not cause toxic adverse effects on the invertebrate $B$. glabrata at the exposure time. However, MT affected $B$. glabrata reproduction, especially at the lowest concentration of $0.01 \mathrm{mg} / \mathrm{L}$, increasing egg mass production $(\mathrm{P}<0.05)$ to levels similar to the solvent control group (Figure 1). Stress-induced altering of endocrinal regulation of foraging/ feeding behavior through exposure to compounds affecting endocrinal processes can have strong repercussions on the ecology of aquatic invertebrate populations and requires further ecotoxicological investigations.

As recommended by Smith (1974), the ethanol concentration used in our experiments did not exceed $0.001 \%$. Ethanol used as a solvent in reproductive assays on invertebrates is sometimes controversial, because some authors recommend that the maximum concentration 
of ethanol does not exceed $20 \mu \mathrm{L} / \mathrm{L}$, whereas others report no interference in reproduction of invertebrate species at an ethanol concentration of $100 \mu \mathrm{L} / \mathrm{L}$ (Hutchinson et al., 2006). It was observed that MT associated with ethanol might have stimulated sperm production and reproduction as judged by comparison with unexposed controls. Results of the solvent control group showed that $B$. glabrata exposure to a concentration of $0.001 \%$ ethanol might have influenced its reproductive performance, stimulating the egg masses at the lowest concentration of 0.01 $\mathrm{mg} / \mathrm{L}$ and increasing sperm production at higher concentrations of 0.1 and $1.0 \mathrm{mg} / \mathrm{L}$ when compared to the water control. In our previous study with B. tenagophila, ethanol was tested at concentrations of $19.8,198.0$, and $1980.0 \mathrm{mg} / \mathrm{L}$ (corresponding to $0.0025,0.025$, and $0.25 \%$, $\mathrm{v} / \mathrm{v})$. This resulted in a reduction of fecundity in F0 and F1 at ethanol levels of $\geq 198.0 \mathrm{mg} / \mathrm{L}$ and drastically reduced hatching of F2 embryos (Oliveira-Filho et al., 2009a). Hana et al. (2008) diluted testosterone propionate at 0.83 and $0.89 \mathrm{~g}$ per $30 \mathrm{~mL}$ ethanol to carry out genotoxic and reproductive assays on mice. In discussing their results, the authors do not refer to any kind of interference of ethanol in these assays. Janer et al. (2006) tested the effects of testosterone on reproduction of the freshwater ramshorn snail Marisa cornuarietis. Testosterone was added in absolute ethanol at a final concentration in water of $0.001 \%$, and snails were exposed to these agents for 50,100, and 150 days. These authors also do not note any interference of ethanol in their results. However, according to our results, ethanol can interfere with the reproductive performance of $B$. glabrata. The stimulation of egg mass and sperm production observed in the ethanol control group and at the highest concentrations of 0.1 and $1.0 \mathrm{mg} / \mathrm{L}$ may be related to a carrier effect of the ethanol solvent, facilitating the entry of MT into snail cells. In terms of environmental risk assessment, we might consider that MT used to feed fish larvae on fish farms could also contain residues of ethanol, so by using ethanol we have tested what may be occurring in the field. On fish hatchery, MT is commonly dissolved in ethanol before application.

MT and metabolites discharged into receiving waters are expected to undergo biotransformation. Evidence for such transformation was present in our chromatographic analyses to monitor the fate of MT during our experiments: within a week, MT was almost completely degraded under our conditions. Degradation of MT in natural conditions is expected to be faster because of biodegradation and photodegradation.

In conclusion, MT affected the reproductive performance of $B$. glabrata, a non-target species. Exposure of B. glabrata to MT did not alter oocyte maturation, but it influenced sperm production and number of egg masses produced. Synergism between MT and the solvent ethanol may have induced these effects and both are used in field applications. These results highlight the importance of providing more information to regulatory authorities, since the MT hormone is not registered for use on fish hatchery in many countries around the world. Chromatographic analyses of water samples indicated that MT was rapidly degraded within 1 week in laboratory conditions and in the absence of replenishment. This suggests that the potential reproductive risks of MT could be related to the rate of its consumption and degradation. Fish hatchery effluents discharged into aquatic ecosystems should be monitored for MT residues, since MT could compromise the reproduction of many native snail species.

\section{ACKNOWLEDGMENTS}

Research supported by the Ministry of Fisheries (grant \#578541/2008-4), the Brazilian National Council for Technological and Scientific Development $(\mathrm{CNPq})$, and the Brazilian Enterprise for Agricultural Research (EMBRAPA). 


\section{REFERENCES}

Abd-Allah AT, Thompson SN, Borchardt DB and Wanas MQA (1999). Biomphalaria glabrata: a laboratory model illustrating the potential of pulmonate gastropods as freshwater biomonitoring of heavy metal pollutants. Malacologia 41: 345-353.

ABNT (2004). NBR 12713: Ecotoxicologia Aquática - Toxicidade Aguda - Método de Ensaio com Daphnia spp (Cladocera, Crustacea). Associação Brasileira de Normas Técnicas, Rio de Janeiro.

Ankley GT, Jensen KM, Kahl MD, Korte JJ, et al. (2001). Description and evaluation of a short-term reproduction test with the fathead minnow (Pimephales promelas). Environ. Toxicol. Chem. 20: 1276-1290.

Ansaldo M, Nahabedian DE, Holmes-Brown E, Agote M, et al. (2006). Potential use of glycogen level as biomarker of chemical stress in Biomphalaria glabrata. Toxicology 224: 119-127.

Arslan T and Phelps RP (2004). Production of monosex male black crappie, Pomoxis nigromaculatus, populations by multiple androgen immersion. Aquaculture 234: 561-573.

Cervera A, Maymó AC, Sendra M, Martínez-Pardo R, et al. (2004). Cadmium effects on development and reproduction of Oncopeltus fasciatus (Heteroptera: Lygaeidae). J. Insect. Physiol. 50: 737-749.

Cheung CCC and Lam PKS (1998). Effect of cadmium on the embryos and juveniles of a tropical freshwater snail Physa acuta (Draparnaud, 1805). Water Sci. Technol. 38: 263-270.

Coeurdassier M, de Vaufleury A and Badot PM (2003). Bioconcentration of cadmium and toxic effects on life-history traits of pond snails (Lymnaea palustris and Lymnaea stagnalis) in laboratory bioassays. Arch. Environ. Contam Toxicol. 45: 102-109.

Coeurdassier M, de Vaufleury A, Scheifler R, Morhain E, et al. (2004). Effects of cadmium on the survival of three lifestages of the freshwater pulmonate Lymnaea stagnalis (Mollusca: Gastropoda). Bull. Environ. Contam. Toxicol. 72: 1083-1090.

Coeurdassier M, de Vaufleury A, Crini N, Scheifler R, et al. (2005). Assessment of whole effluent toxicity on aquatic snails: bioaccumulation of $\mathrm{Cr}, \mathrm{Zn}$, and Fe, and individual effects in bioassays. Environ. Toxicol. Chem. 24: 198-204.

Czech P, Weber K and Dietrich DR (2001). Effects of endocrine modulating substances on reproduction in the hermaphroditic snail Lymnaea stagnalis L. Aquat. Toxicol. 53: 103-114.

Duft M, Schmitt C, Bachmann J, Brandelik C, et al. (2007). Prosobranch snails as test organisms for the assessment of endocrine active chemicals - an overview and a guideline proposal for a reproduction test with the freshwater mudsnail Potamopyrgus antipodarum. Ecotoxicology 16: 169-182.

Dunnett CW (1955). Multiple comparison procedure for comparing several treatments with a control. J. Am. Stat. Assoc. 50: 1096-1121.

Elder JF and Collins JJ (1991). Freshwater molluscs as indicators of bioavailability and toxicity of metals in surface-water systems. Rev. Environ. Contam. Toxicol. 122: 37-79.

Falone SZ (2007). Desenvolvimento de Métodos para a Determinação do Hormônio 17-Alfa-Metiltestosterona em Amostras de Água e de Sedimentos de Piscicultura: Ensaios Ecotoxicológicos com Cladóceros. Tese de Doutorado em Ciências da Engenharia Ambiental, Universidade de São Paulo.

Gist GL (1998). National environmental health association position on endocrine disrupters. J. Environm. Health 60: 21.

Gomot A (1998). Toxic effects of cadmium on reproduction, development, and hatching in the freshwater snail Lymnaea stagnalis for water quality monitoring. Ecotoxicol. Environ. Saf. 41: 288-297.

Gourmelon A and Ahtiainen J (2007). Developing Test Guidelines on invertebrate development and reproduction for the assessment of chemicals, including potential endocrine active substances - the OECD perspective. Ecotoxicology 16: 161-167.

Grisolia CK, Rivero CL, Starling FL, da Silva IC, et al. (2009). Profile of micronucleus frequencies and DNA damage in different species of fish in a eutrophic tropical lake. Genet. Mol. Biol. 32: 138-143.

Gupta SK and Singh J (2011). Evaluation of mollusc as sensitive indicatior of heavy metal pollution in aquatic system: A Review. IIOAB J. 2: 49-57.

Hana HY, Khalil WK, Elmakawy AI and Elmegeed GA (2008). Androgenic profile and genotoxicity evaluation of testosterone propionate and novel synthesized heterocyclic steroids. J. Steroid. Biochem. Mol. Biol. 110: 284-294.

Homklin S, Ong SK and Limpiyakorn T (2011). Biotransformation of 17alpha-methyltestosterone in sediment under different electron acceptor conditions. Chemosphere 82: 1401-1407.

Hornung MW, Jensen KM, Korte JJ, Kahl MD, et al. (2004). Mechanistic basis for estrogenic effects in fathead minnow (Pimephales promelas) following exposure to the androgen 17alpha-methyltestosterone: conversion of 17alphamethyltestosterone to 17alpha-methylestradiol. Aquat. Toxicol. 66: 15-23.

Hutchinson TH, Shillabeer N, Winter MJ and Pickford DB (2006). Acute and chronic effects of carrier solvents in aquatic organisms: a critical review. Aquat. Toxicol. 76: 69-92. 
Iqbal MT and Sinha S (2011). Environmental endocrine disruptors and their effects on Biomphalaria glabrata oviposition. J. Vector Borne Dis. 48: 174-176.

Janer G, Lyssimachou A, Bachmann J, Oehlmann J, et al. (2006). Sexual dimorphism in esterified steroid levels in the gastropod Marisa cornuarietis: the effect of xenoandrogenic compounds. Steroids 71: 435-444.

Jha AN (1998). Use of aquatic invertebrates in genotoxicological studies. Mutat. Res. 399: 1-2.

Kang IJ, Yokota H, Oshima Y, Tsuruda Y, et al. (2008). The effects of methyltestosterone on the sexual development and reproduction of adult medaka (Oryzias latipes). Aquat. Toxicol. 87: 37-46.

Nakano E, Watanabe LC, Ohlweiler FP, Pereira CA, et al. (2003). Establishment of the dominant lethal test in the freshwater mollusk Biomphalaria glabrata (Say, 1818). Mutat. Res. 536: 145-154.

Oliveira-Filho EC, Grisolia CK and Paumgartten FJ (2009a). Effects of endosulfan and ethanol on the reproduction of the snail Biomphalaria tenagophila: a multigeneration study. Chemosphere 75: 398-404.

Oliveira-Filho EC, Grisolia CK and Paumgartten FJ (2009b). Trans-generation study of the effects of nonylphenol ethoxylate on the reproduction of the snail Biomphalaria tenagophila. Ecotoxicol. Environ. Saf. 72: 458-465.

Olivier L and Haskins WT (1960). The effects of low concentrations of sodium pentachlorophenate on the fecundity and egg viability of Australorbis glabratus. Am. J. Trop. Med. Hyg. 9: 199-205.

Pandian TJ and Sheela SG (1995). Hormonal induction of sex reversal in fish. Aquaculture 138: 1-22.

Papoulias DM, Noltie DB and Tillitt DE (2000). Effects of methyl testosterone exposure on sexual differentiation in medaka, Oryzias latipes. Mar. Environ. Res. 50: 181-184.

Paraense WL (1972). Fauna Planorbídica do Brasil. In: Introdução à Geografia Médica do Brasil (Lacaz CS, Baruzzi RG and Siqueira JW, eds.). Edgar Blucher, São Paulo, 213-239.

Pawlowski S, Sauer A, Shears JA, Tyler CR, et al. (2004). Androgenic and estrogenic effects of the synthetic androgen 17alpha-methyltestosterone on sexual development and reproductive performance in the fathead minnow (Pimephales promelas) determined using the gonadal recrudescence assay. Aquat. Toxicol. 68: 277-291.

Smith RJ (1974). Effects of 17alpha-methyltestosterone on the dorsal pad and tubercles of fathead minnows (Pimephales promelas). Can. J. Zool. 52: 1031-1038.

Swan SH, Elkin EP and Fenster L (2000). The question of declining sperm density revisited: an analysis of 101 studies published 1934-1996. Environ. Health Perspect. 108: 961-966.

Vick AM and Hayton WL (2001). Methyltestosterone pharmacokinetics and oral bioavailability in rainbow trout (Oncorhynchus mykiss). Aquat. Toxicol. 52: 177-188.

Wallace RA and Selman K (1981). Cellular and dynamic aspects of oocyte growth in teleosts. Am. Zool. 21: 325-343.

Zerulla M, Länge R, Steger-Hartmann T, Panter G, et al. (2002). Morphological sex reversal upon short-term exposure to endocrine modulators in juvenile fathead minnow (Pimephales promelas). Toxicol. Lett. 131: 51-63. 